\title{
Risk factors for the development of severe typhoid fever in Vietnam
}

Christopher M Parry ${ }^{1,2^{*}}$, Corinne Thompson ${ }^{1,3}$, Ha Vinh $^{4}$, Nguyen Tran Chinh ${ }^{4}$, Le Thi Phuong ${ }^{5}$, Vo Anh Ho ${ }^{5}$, Tran Tinh Hien ${ }^{1,4}$, John Wain ${ }^{1,6}$, Jeremy J Farrar ${ }^{1,3}$ and Stephen Baker ${ }^{1,3,7}$

\begin{abstract}
Background: Typhoid fever is a systemic infection caused by the bacterium Salmonella enterica serovar Typhi. Age, sex, prolonged duration of illness, and infection with an antimicrobial resistant organism have been proposed risk factors for the development of severe disease or fatality in typhoid fever.

Methods: We analysed clinical data from 581 patients consecutively admitted with culture confirmed typhoid fever to two hospitals in Vietnam during two periods in 1993-1995 and 1997-1999. These periods spanned a change in the antimicrobial resistance phenotypes of the infecting organisms i.e. fully susceptible to standard antimicrobials, resistance to chloramphenicol, ampicillin and trimethoprim-sulphamethoxazole (multidrug resistant, MDR), and intermediate susceptibility to ciprofloxacin (nalidixic acid resistant). Age, sex, duration of illness prior to admission, hospital location and the presence of MDR or intermediate ciprofloxacin susceptibility in the infecting organism were examined by logistic regression analysis to identify factors independently associated with severe typhoid at the time of hospital admission.

Results: The prevalence of severe typhoid was 15.5\% (90/581) and included: gastrointestinal bleeding (43; 7.4\%); hepatitis (29; 5.0\%); encephalopathy (16; 2.8\%); myocarditis (12; 2.1\%); intestinal perforation (6; 1.0\%); haemodynamic shock $(5 ; 0.9 \%)$, and death $(3 ; 0.5 \%)$. Severe disease was more common with increasing age, in those with a longer duration of illness and in patients infected with an organism exhibiting intermediate susceptibility to ciprofloxacin. Notably an MDR phenotype was not associated with severe disease. Severe disease was independently associated with infection with an organism with an intermediate susceptibility to ciprofloxacin (AOR 1.90; 95\% Cl 1.18-3.07; $p=0.009)$ and male sex (AOR $1.61(1.00-2.57 ; p=0.035)$.
\end{abstract}

Conclusions: In this group of patients hospitalised with typhoid fever infection with an organism with intermediate susceptibility to ciprofloxacin was independently associated with disease severity. During this period many patients were being treated with fluoroquinolones prior to hospital admission. Ciprofloxacin and ofloxacin should be used with caution in patients infected with S. Typhi that have intermediate susceptibility to ciprofloxacin.

Keywords: Salmonella enterica serovar Typhi, Severe typhoid, Antimicrobial resistance, Multidrug resistance, Intermediate ciprofloxacin susceptibility

\footnotetext{
* Correspondence: cmparry@liverpool.ac.uk

${ }^{1}$ Wellcome Trust Major Overseas Programme, Oxford University Clinical

Research Unit, Hospital for Tropical Diseases, 764 Vo Van Kiet, District 5, Ho

Chi Minh City, Vietnam

${ }^{2}$ Department of Clinical Sciences, Liverpool School of Tropical Medicine,

Pembroke Place, Liverpool, L3 5QA, UK

Full list of author information is available at the end of the article
} reproduction in any medium, provided the original work is properly cited. The Creative Commons Public Domain Dedication waiver (http://creativecommons.org/publicdomain/zero/1.0/) applies to the data made available in this article, unless otherwise stated. 


\section{Background}

Typhoid fever, caused by Salmonella enterica serovar Typhi (S. Typhi) and Salmonella enterica serovar Paratyphi A (S. Paratyphi A), has been estimated to cause approximately 27 million infections each year worldwide [1]. The disease is common in parts of Asia particularly among children [2]. Fatality rates in the pre-antimicrobial era ranged from 7 $26 \%$ of hospitalised cases [3-5]. The introduction of chloramphenicol, and subsequently, other antimicrobial agents, led to a marked reduction in the occurrence of severe and fatal disease $[4,5]$. Despite improvements in treatment, some patients, particularly the very young and elderly, and those receiving inadequate antimicrobial therapy, continue to develop severe and life threatening disease [5-7].

Since the early1990s multidrug-resistant (MDR) strains of S. Typhi and S. Paratyphi A (resistant to chloramphenicol, trimethoprim/sulphamethoxazole and ampicillin) have not only caused epidemics, but have become endemic across some parts of Asia [2,8]. Similarly, isolates of $S$. Typhi and $S$. Paratyphi A with intermediate susceptibility to ciprofloxacin (formerly called decreased susceptibility and indicated in the laboratory by resistance to nalidixic acid or with a minimum inhibitory concentration (MIC) between 0.1 and $0.5 \mu \mathrm{g} / \mathrm{mL}$ against ciprofloxacin) are now common in endemic areas and in imported infections in industrialised countries $[8,9]$. Intermediate susceptibility to ciprofloxacin has been associated with longer fever clearance time and treatment failures when either ciprofloxacin or ofloxacin are used for treatment $[10,11]$.

Severe or fatal typhoid fever has been reported to be associated with extremes of age, female and male sex and prolonged illness $[4,6,7,12-16]$. Infection with antimicrobial resistant isolates (MDR and nalidixic acid resistant) has also been proposed to correlate with the development of severe infection $[6,16,17]$. The association of antimicrobial resistance with severe disease may result from a delay in the initiation of appropriate antimicrobial therapy, but may also potentially be the result of a genotypic association that increases the pathogenic potential of infecting organism.

We aimed to determine microbiological and clinical factors associated with increased risk of severe typhoid fever, hypothesising that the changing antimicrobial resistance phenotypes throughout the selected study periods in Vietnam were associated with a shift in disease severity. We used a logistic regression model to assess the influence of age, sex, duration of illness prior to hospital admission, and the antimicrobial resistance profile of the infecting isolate on the clinical severity of typhoid.

\section{Methods}

\section{Patients studied}

This analysis was performed on data from patients at two hospitals in southern Vietnam between May 1993-
July 1995 and April 1997-February 1999. The two hospitals were The Hospital for Tropical Diseases (HTD) in Ho Chi Minh City (HCMC) and Dong Thap Provincial Hospital (DTPH) in Cao Lanh, Dong Thap Province. HTD is a 500-bed infectious disease hospital with a catchment area encompassing HCMC and is a referral hospital for the surrounding province and DTPH is a 400-bed general hospital, serving the population of Cao Lanh and is a referral centre for the province of Dong Thap in the Mekong Delta. During these time periods consecutive patients with blood or bone marrow culture confirmed typhoid were included in antimicrobial treatment, diagnostic, pathophysiology and surveillance studies at the two hospitals [17-27]. There were only a small number of patients with paratyphoid and they were excluded from this analysis.

Each individual study independently received approval from the scientific and ethical committee of the respective hospital prior to the initiation of the study. Patients, or the parent or guardian for children, gave informed verbal consent before entry into the studies. The studies were conducted in accordance with the Declaration of Helsinki. This was a post-hoc analysis of the existing prospectively collected anonymised patient and laboratory data from these studies. No additional data collection or laboratory analysis was performed.

\section{Clinical data}

Demographic, clinical and laboratory data was prospectively gathered on standardised case report forms at the time of hospital admission. For continuous variables patients were categorised according to the presence with in the first 24 hours of admission of; a peak temperature of $>40.0^{\circ} \mathrm{C}$, a systolic blood pressure of $<90 \mathrm{mmHg}$, a haematocrit of $<30 \%$, an elevated white cell count (defined as $>15 \times 10^{9} / \mathrm{L}$ ), a low white cell count (defined as $<4 \times$ $10^{9} / \mathrm{L}$ ), a low platelet count (defined as $<100 \times 10^{9} / \mathrm{L}$ ), an elevated SGOT (defined as $>200 \mathrm{IU} / \mathrm{L}$ which was approximately five times upper limit of normal) and an elevated SGPT (defined as > 200 IU/L which was approximately five times upper limit of normal). Clinical outcomes (death or resolution) were recorded for all patients. Patients who were readmitted as relapse cases were only included for the initial admission. Information concerning antimicrobial agents used for treatment prior to hospital admission was not reliably available.

Severe disease was defined by the presence of one or more of the following features: gastrointestinal bleeding (the presence of visible blood in the stool), intestinal perforation (confirmed at surgery), encephalopathy (delirium, obtundation or coma), haemodynamic shock (systolic blood pressure $<90 \mathrm{mmHg}$ and/or diastolic blood pressure $<60 \mathrm{mmHg}$ associated with tissue hypoperfusion), myocarditis (tachycardia or bradycardia with an associated 
abnormality of the ECG or ultrasound evidence of a pericardial effusion), hepatitis (as indicated by jaundice and/or hepatomegaly with abnormal levels of SGOT (> $400 \mathrm{IU} / \mathrm{L}$ ) and/or SGPT (>400 IU/L)), a clinical diagnosis of cholecystitis (right upper quadrant pain and tenderness without evidence of hepatitis), pneumonia (respiratory symptoms with abnormal chest X-ray infiltrates) or pleural effusion, severe anaemia (haematocrit $\leq 20 \%$ ), the need for a blood transfusion, or death.

\section{Microbiological methods}

Blood or bone marrow aspirates was added to brain heart infusion broth containing sodium polyethanolsulphonate $(1: 10)$ and incubated at $35-37^{\circ} \mathrm{C}$ for seven days. Sub-cultures were performed after one, two and seven days or when the broth went turbid. Alternatively, blood was inoculated into BACTEC bottles (Becton-Dickenson, USA) and cultured for five days in a BACTEC 9050 automated incubator. Bottles that gave a positive signal were sub-cultured. Salmonella isolates were identified by standard biochemical tests and agglutination with Salmonella specific antisera (Murex diagnostics, Dartford, United Kingdom). Antimicrobial sensitivities were performed at the time of isolation by a modified Bauer-Kirby disc diffusion method and inhibition zone sizes were recorded. Interpretations of the zone sizes were based on the current (2013) CLSI guidelines [28]. The antimicrobials tested (Unipath, Basingstoke, United Kingdom) were chloramphenicol $(30 \mu \mathrm{g})$, ampicillin $(10 \mu \mathrm{g})$, trimethoprimsulphamethoxazole $(1.25 / 23.75 \mu \mathrm{g})$, ceftriaxone $(30 \mu \mathrm{g})$, ofloxacin $(5 \mu \mathrm{g})$, azithromycin $(15 \mu \mathrm{g})$ and nalidixic acid $(30 \mu \mathrm{g})$. Isolates were stored in Protect beads (Prolabs, Oxford, United Kingdom) at $-20^{\circ} \mathrm{C}$.

Stored bacterial isolates were later sub-cultured onto nutrient agar and the MICs for the isolates were determined by the standard agar plate dilution method according to CLSI guidelines or using E- test strips according to the manufacturer's guidelines (AB Biodisk, Solna, Sweden). The evaluated antimicrobials were ciprofloxacin $(0.008 \mu \mathrm{g} / \mathrm{mL}$ to $4 \mu \mathrm{g} / \mathrm{mL})$, ofloxacin $(0.008$ $\mu \mathrm{g} / \mathrm{mL}$ to $4 \mu \mathrm{g} / \mathrm{mL})$ and nalidixic acid $(0.5 \mu \mathrm{g} / \mathrm{mL}$ to 512 $\mu \mathrm{g} / \mathrm{mL})$. Antimicrobial powders were purchased from Sigma, United Kingdom, except for ofloxacin, which was donated from Hoescht Marion Roussel. Escherichia coli ATCC $^{\ominus} 25922$ and Staphylococcus aureus ATCC ${ }^{\bullet}$ 25923 were used as control strains for these assays. An isolate was defined as MDR if it was resistant to chloramphenicol $(\geq 32 \mu \mathrm{g} / \mathrm{ml})$, trimethoprim/sulphamethoxazole $(\geq 8 / 152 \mu \mathrm{g} / \mathrm{ml})$ and ampicillin $(\geq 32 \mu \mathrm{g} / \mathrm{ml})$. An isolate was defined as having intermediate ciprofloxacin susceptibility if it was resistant to nalidixic acid $(\geq 32 \mu \mathrm{g} / \mathrm{ml})$ and/or had a ciprofloxacin MIC of $0.1-0.5 \mu \mathrm{g} / \mathrm{ml}$ and/or ofloxacin MIC of $0.25-1.0 \mu \mathrm{g} / \mathrm{ml}$.

\section{Analysis}

Demographic and clinical features were described for the whole cohort and within the stratified age categories of $<5$ years, $5-15$ years and $\geq 16$ years. Continuous data was described using median and inter-quartile range and compared using the Mann Whitney $U$-test. Proportions were compared with the Chi squared test or the Fisher's exact test as appropriate. Age, sex, duration of illness prior to admission to hospital, the presence of an MDR phenotype and intermediate susceptibility to ciprofloxacin were evaluated for association with severe or fatal typhoid fever through a univariate analysis. A multivariate logistic regression model controlling simultaneously for the effects of confounding included variables associated with the outcome of severity $(\mathrm{p}<0.10)$ as well as a priori factors age, sex and site. Statistical analysis was performed using STATA version 11 (StataCorp, Texas, USA).

\section{Results}

\section{Demographic data and diagnostic test results}

Data was available for analysis on a total of 581 patients with culture confirmed typhoid fever. There were 347 typhoid patients during 1993 and 1995 and 234 during 1997 and 1999. The final dataset included 355 (61.1\%) children ( $<16$ years), with $44(7.6 \%)$ under the age of 5 years, and $226(38.9 \%)$ adults ( $\geq 16$ years) (Figure 1 ). There were 296 (50.9\%) males, comprised of 196 (55.2\%) male children and 100 (43.2\%) male adults. A blood and bone marrow culture was performed with material from 193 (33\%) patients and blood culture alone was performed

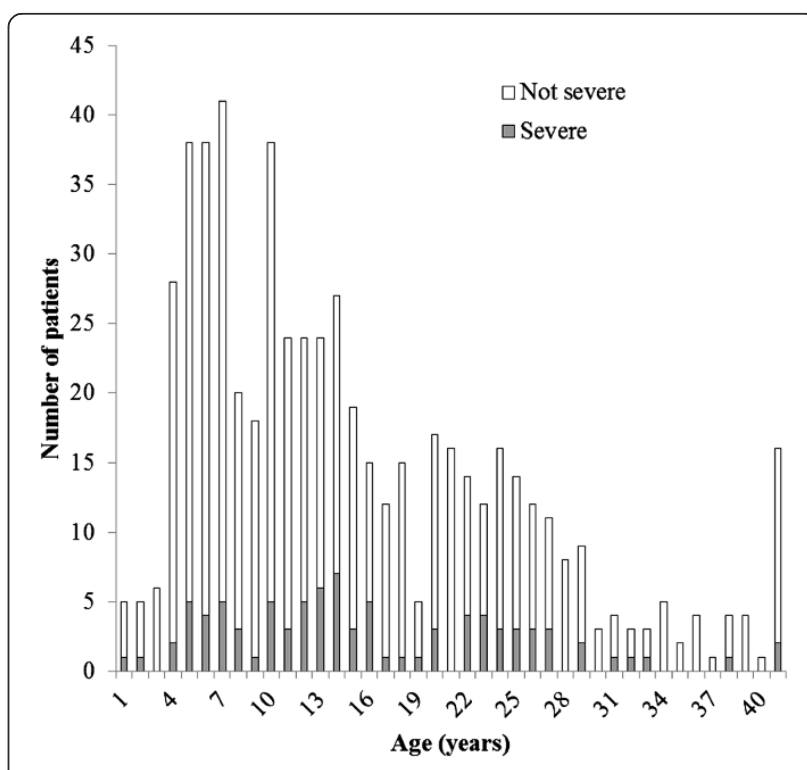

Figure 1 The age distribution and severity in $\mathbf{5 8 1}$ hospitalised Vietnamese patients with typhoid fever between 1993 and 1999. 
on $388(67 \%)$ patients. Notably, in the patients receiving both blood and bone marrow cultures, $S$. Typhi was isolated from both samples on 145 (25\%) occasions and from the bone marrow alone on 28 (5\%) occasions.

\section{The clinical and microbiological features of typhoid on hospital admission}

The signs and symptoms of the enrolled patients at the time of admission are summarised in Table 1 and classified by age range. Children under 16 years old were more likely than adults to have a shorter duration of illness, constipation and a cough. Abdominal pain and vomiting was most commonly recorded in school-aged children, and adults were more likely than children to have a headache. More than half of all enrolled subjects had diarrhoea and a peak temperature in excess of $40^{\circ} \mathrm{C}$. Children under 16 years old were more likely to have hepatopslenomegaly and were more frequently infected with an MDR or intermediate ciprofloxacin susceptibility organism.

\section{Clinical outcomes and the prevalence of severe typhoid}

The clinical outcomes of the enrolled typhoid patients are summarised in Table 2 and classified by age range. The prevalence of severe or fatal typhoid at the time of admission in this group of patients was $15.5 \%$ (90/581). The most common complications associated with severe disease were gastrointestinal bleeding (43; 7.4\%); hepatitis (29; $5.0 \%)$; encephalopathy (16; $2.8 \%)$; myocarditis (12; $2.1 \%)$; pneumonia or pleural effusion $(11 ; 1.9 \%)$; intestinal perforation $(6 ; 1.0 \%)$; and haemodynamic shock $(5 ; 0.9 \%)$. Severe disease was slightly more frequent in adults (39/ $226 ; 17.3 \%)$ than in children under 16 years $(51 / 355$; $14.4 \%$ ) (Figure 1). The overall case fatality rate was $3 / 581$ $(0.5 \%)$. All these three fatal cases were adults with combined encephalopathy and haemodynamic shock. The six patients with intestinal perforation, all male, were managed successfully with surgery and antimicrobial therapy. The clinical and laboratory features associated with severe disease are shown in Table 3.

\section{Risk factors associated with severe typhoid infections}

Associations between age, sex, duration of illness prior to admission, hospital site and infection with an organism with an MDR or intermediate ciprofloxacin susceptibility phenotype with severe disease are shown in Table 4. All of these variables were evaluated for associations with severe typhoid through a logistic regression model. After controlling for the effects of confounding, severe disease was independently associated with infection with an organism with intermediate resistance to ciprofloxacin (AOR 1.90; 95\% CI 1.18-3.07; $\mathrm{p}=0.009$ ) and male sex (AOR 1.04 (1.00-2.57; $\mathrm{p}=0.048)$.
We hypothesised that the observed association between infection with an organism exhibiting intermediate resistance to ciprofloxacin and disease severity may be related to these individuals having a longer duration of illness before hospital admission, as a result of initially receiving ineffective treatment. However, the median duration of illness prior to hospitalisation for patients infected with an organism with intermediate ciprofloxacin resistance was 8 (IQR: 6-10) days and for patients infected with a ciprofloxacin susceptible organism was also 8 (IQR: 6-13) days $(p=$ 0.081).

\section{Discussion}

In this study of 581 Vietnamese patients hospitalised with acute typhoid we identified an independent association of infection with isolates with intermediate susceptibility to ciprofloxacin with severe typhoid. Our research and the research of other groups have previously discussed an impaired response to ofloxacin and ciprofloxacin among patients infected with a ciprofloxacin intermediate isolate $[10,11]$. A retrospective report in children and adults from New Dehli, India showed an association between severe disease and MDR strains and strains with a decreased susceptibility to fluoroquinolones [16]. In the multivariate analysis in the New Dehli study this relationship with severe disease remained significant for strains exhibiting a decreased susceptibility to fluoroquinolones (OR 3.96, 95\% CI 1.39-11.24, $\mathrm{p}=0.004)$. During the period of the study fluoroquinolones, such as ofloxacin and ciprofloxacin, became widely available for treating typhoid infections caused by MDR organisms in outpatients, private clinics and hospitals. Such treatment would be less effective initial treatment for strains with intermediate susceptibility to ciprofloxacin. We anticipated that this might result in a delayed presentation to hospital for patients infected with such strains. In fact there was no significant difference in the duration of illness before admission in these patients compared with those infected with ciprofloxacin susceptible strains.

Our analyses found that severe or fatal disease was slightly more common in adults than children. Previous data regarding the severity of typhoid in children and adults demonstrates variability. Some studies describe typhoid as a severe disease in young children $[6,7,13,14]$, but others characterise it as a comparatively mild, even benign, illness [29-31]. This feature of our findings may lack some generalisability, as severely ill children resident in HCMC may be admitted to one of two specialist paediatric hospitals rather than HTD. Furthermore, typhoid in very young children ( $<5$ years) may present with unspecific clinical features such as syndromic sepsis, pneumonia, diarrhoea or a viral syndrome and may not be recognised as clinical typhoid [31]. We also found that that severe disease was more common in males and all 
Table 1 The demographics and clinical features of 581 typhoid fever patients categorised by age

\begin{tabular}{|c|c|c|c|c|c|c|}
\hline Covariate & $\begin{array}{l}\text { All ages } \\
n=581\end{array}$ & $\begin{array}{c}<5 \text { years } \\
n=44\end{array}$ & $\begin{array}{c}\text { 5-15 years } \\
\mathrm{n}=311\end{array}$ & $\begin{array}{c}\geq 16 \text { years } \\
n=226\end{array}$ & $\underset{\text { value }^{1}}{\mathbf{p}}$ & value $^{p}$ \\
\hline \multicolumn{7}{|l|}{ Baseline } \\
\hline \multicolumn{7}{|l|}{ Year $^{3}$} \\
\hline 1993-1995 & $347(59.7)$ & $26(7.5)$ & $177(51.0)$ & $144(41.5)$ & 0.785 & 0.117 \\
\hline 1997-1999 & $234(40.3)$ & $18(17.7)$ & $134(57.3)$ & $82(35.0)$ & & \\
\hline \multicolumn{7}{|l|}{ Site $^{4}$} \\
\hline Ho Chi Minh City & $350(60.2)$ & $24(6.9)$ & $136(38.9)$ & $190(54.3)$ & 0.177 & $<0.001$ \\
\hline Dong Thap & $231(39.8)$ & $20(8.7)$ & $175(75.6)$ & $36(15.6)$ & & \\
\hline Male sex & $296(50.9)$ & $28(63.6)$ & $168(53.8)$ & $100(45.3)$ & 0.230 & 0.010 \\
\hline Days ill prior to admission ${ }^{5}$ & $8(6-11)$ & $7(6-10)$ & $7(6-10)$ & $9(7-14)$ & 0.813 & $<0.001$ \\
\hline \multicolumn{7}{|l|}{ Signs \& symptoms } \\
\hline Abdominal pain & $178(30.6)$ & $9(20.5)$ & $129(41.5)$ & $40(17.7)$ & 0.007 & $<0.001$ \\
\hline Constipation & $134(23.1)$ & $10(22.7)$ & $107(34.4)$ & $17(7.5)$ & 0.123 & $<0.001$ \\
\hline Diarrhoea & $321(55.2)$ & $26(59.1)$ & $177(56.9)$ & $118(52.2)$ & 0.785 & 0.240 \\
\hline Vomiting & $116(20)$ & $5(11.4)$ & $75(24.1)$ & $36(15.9)$ & 0.081 & 0.052 \\
\hline Cough & $131(22.5)$ & $15(34.1)$ & $79(25.4)$ & $37(16.4)$ & 0.221 & 0.004 \\
\hline Headache & $220(37.9)$ & $5(11.4)$ & 117 (37.6) & $98(43.4)$ & $<0.001$ & 0.029 \\
\hline Temperature $>40^{\circ} \mathrm{C}$ & $318(54.7)$ & $27(61.4)$ & $180(58.6)$ & $111(53.1)$ & 0.730 & 0.175 \\
\hline${ }^{6} \mathrm{SBP}<90 \mathrm{mmHg}$ & $25(4.3)$ & $2(4.5)$ & $14(4.5)$ & $9(4.0)$ & 1.000 & 0.761 \\
\hline Hepatomegaly & $303(52.2)$ & $31(70.5)$ & $222(71.4)$ & $50(22.1)$ & 0.899 & $<0.001$ \\
\hline Jaundice & $17(2.9)$ & $0(0)$ & $11(3.5)$ & $6(2.7)$ & 0.372 & 0.757 \\
\hline Splenomegaly & $101(17.4)$ & $10(22.7)$ & $72(23.2)$ & $19(8.4)$ & 0.950 & $<0.001$ \\
\hline Rash & $15(2.6)$ & $1(2.3)$ & $10(3.2)$ & $4(1.8)$ & 1.000 & 0.426 \\
\hline \multicolumn{7}{|l|}{ Laboratory } \\
\hline${ }^{7}$ Haematocrit $<30 \%$ & $72(12.4)$ & $7(18.4)$ & $52(17.4)$ & $13(7.2)$ & 0.875 & 0.001 \\
\hline${ }^{8}$ White cell count $<4 \times 10^{9} / \mathrm{L}$ & $40(6.9)$ & $2(4.5)$ & $19(6.1)$ & $19(8.4)$ & 1.000 & 0.251 \\
\hline${ }^{8}$ White cell count $>15 \times 10^{9} / \mathrm{L}$ & $11(1.9)$ & $2(4.5)$ & $6(1.9)$ & $3(1.3)$ & 0.261 & 0.541 \\
\hline${ }^{9}$ Platelet count $<100 \times 10^{9} / \mathrm{L}$ & $27(4.6)$ & $2(5.7)$ & $13(5.3)$ & $12(9.0)$ & 1.000 & 0.165 \\
\hline${ }^{10} \mathrm{SGOT}>200 \mathrm{IU} / \mathrm{L}$ & $63(10.8)$ & $3(21.4)$ & $43(32.8)$ & $17(22.7)$ & 0.549 & 0.159 \\
\hline${ }^{10} \mathrm{SGPT}>200 \mathrm{IU} / \mathrm{L}$ & $44(7.6)$ & $0(0)$ & $26(19.8)$ & $18(24.0)$ & 0.075 & 0.286 \\
\hline \multicolumn{7}{|l|}{ Isolate } \\
\hline Fully susceptible organism & 75 (12.9) & $4(9.1)$ & $30(9.7)$ & $41(18.1)$ & 1.000 & 0.003 \\
\hline MDR & $469(80.7)$ & 39 (88.6) & $261(83.9)$ & $169(74.8)$ & 0.510 & 0.004 \\
\hline Reduced susceptibility to FLQ & $215(37.0)$ & 17 (38.6) & $127(40.8)$ & $71(31.4)$ & 0.781 & 0.026 \\
\hline
\end{tabular}

${ }^{1}$ Comparison of children $<5$ years with children $5-15$ years and ${ }^{2}$ of children $<16$ years with adults $\geq 16$ years by chi square, Fisher's exact or Mann-Whitney $U$ test as appropriate.

${ }^{3}$ Denominators for age groups are the total for each period.

${ }^{4}$ Denominators for age groups are the total for each site.

${ }^{5}$ median (IQR).

${ }^{6} S B P$ - systolic blood pressure.

${ }^{7} \mathrm{n}=518$.

${ }^{8} \mathrm{n}=580$.

${ }^{9} \mathrm{n}=414$.

${ }^{10} \mathrm{n}=220$.

FLQ: Fluoroquinolone.

the cases of intestinal perforation were in males. Previous studies have suggested that disease severity between sexes can vary geographically and has been found to be more common in females $[7,15]$ but also with males, particularly intestinal perforation [4]. It is noteworthy that anaemia was significantly more common among patients with 
Table 2 Outcome in the 581 patients with confirmed typhoid categorised by age group

\begin{tabular}{|c|c|c|c|c|c|c|}
\hline Covariate & $\begin{array}{l}\text { All ages } \\
n=581\end{array}$ & $\begin{array}{c}<5 \text { years } \\
n=44\end{array}$ & $\begin{array}{c}5-15 \text { years } \\
n=311\end{array}$ & $\begin{array}{c}\geq 16 \text { years } \\
n=226\end{array}$ & $p$ value $^{1}$ & p value ${ }^{2}$ \\
\hline Severe or fatal disease & $90(15.5)$ & $4(9.1)$ & $47(15.1)$ & $39(17.3)$ & 0.363 & 0.348 \\
\hline Gastrointestinal bleeding & $43(7.4)$ & $1(2.3)$ & $22(7.1)$ & $20(8.9)$ & 0.334 & 0.287 \\
\hline Intestinal perforation & $6(1.0)$ & $0(0)$ & $2(0.6)$ & $4(1.8)$ & 1.000 & 0.214 \\
\hline Encephalopathy & $16(2.8)$ & $1(2.3)$ & $7(2.3)$ & $8(3.5)$ & 1.000 & 0.437 \\
\hline Myocarditis & $12(2.1)$ & $0(0)$ & $9(2.9)$ & $3(1.3)$ & 0.609 & 0.384 \\
\hline Haemodynamic shock & $5(0.9)$ & $0(0)$ & $0(0)$ & $5(2.2)$ & - & 0.009 \\
\hline Renal impairment & $4(0.7)$ & $0(0)$ & $0(0)$ & $4(1.8)$ & - & 0.023 \\
\hline Hepatitis & $29(5.0)$ & $1(2.3)$ & $18(5.8)$ & $10(4.4)$ & 0.488 & 0.617 \\
\hline Cholecystitis & $4(0.7)$ & $0(0)$ & $3(1.0)$ & $1(0.4)$ & 1.000 & 1.000 \\
\hline Pneumonia & $5(0.9)$ & $1(2.3)$ & $2(0.6)$ & $2(0.9)$ & 0.328 & 1.000 \\
\hline Pleural effusion & $6(1.0)$ & $1(2.3)$ & $3(1.0)$ & $2(0.9)$ & 0.412 & 1.000 \\
\hline Severe anaemia & $6(1.0)$ & $0(0)$ & $5(1.6)$ & $1(0.4)$ & 1.000 & 0.413 \\
\hline Blood transfusion & $3(0.5)$ & $0(0)$ & $2(0.6)$ & $1(0.4)$ & 1.000 & 1.000 \\
\hline Death & $3(0.5)$ & $0(0)$ & $0(0)$ & $3(1.3)$ & - & 0.058 \\
\hline
\end{tabular}

${ }^{1}$ Comparison of children $<5$ years with children $5-15$ years and ${ }^{2}$ of children $<16$ years with adults $\geq 16$ years by chi square, Fisher's exact or Mann-Whitney $U$ test as appropriate.

severe disease. We speculate that the reasons for this are multi-factorial including intestinal bleeding, haemolysis and nutritional.

In this analysis severe disease occurred in $15.5 \%$ of all typhoid patients and fatal disease in $0.5 \%$. These figures are comparable with studies conducted in Pakistan, Bangladesh, India and the United States [6-8,16]. As only approximately $10 \%$ of patients with blood culture confirmed typhoid are hospitalised in this region, these figures likely do not reflect the true frequency of severe disease in the population [32]. The threshold for hospital admission, the availability of antimicrobials in the community without prescription and their use prior to admission will vary between different localities and undoubtedly bias who is admitted to hospital. All the fatal cases from this analysis were adults with encephalopathy and haemodynamic shock; these symptoms have previously been identified as markers of particularly severe disease [33-35].

We found no association of disease severity with an MDR phenotype. In a prospective study of 1,158 children with culture confirmed typhoid fever in Karachi, Bhutta and co-workers found that MDR infections in children in Karachi were associated with higher rates of toxicity, hepatomegaly and hypotensive shock [6]. The $2 \%$ mortality in children with an MDR infection in the study from Pakistan was not significantly higher than the $1.4 \%$ mortality in those infected with an antimicrobial susceptible strain (OR 1.6, 95\% CI; $0.5-4.6, \mathrm{p}=0.34$ ). Notably, intermediate susceptibility to fluoroquinolones was not documented in the study from Pakistan. In a previous investigation in Vietnam, which incorporated some data from the first period of this study, higher bacterial counts in the blood were associated with an MDR phenotype [17].

The reason for more severe disease in those infected with strains with intermediate susceptibility to ciprofloxacin may be more complex than merely a poor response to antimicrobial therapy. We speculate that the genotype of the relevant $S$. Typhi organisms may also play an important role in regulating disease severity. Specifically, we suggest an association between bacterial haplotype (assessed by chromosomal single nucleotide polymorphisms (SNPs)) and the pathogenic potential of the strain. There is currently no $\mathrm{SNP} /$ disease severity data to support this theory. However, S. Typhi isolates originating in Papua New Guinea in the late 1980s and early 1990s exhibited extensive genetic diversity using an insensitive genotyping method (Pulsed field gel electrophoresis (PFGE)), yet a single clone appeared to associated with 11 cases of fatal disease [36]. A further study of $81 \mathrm{~S}$. Typhi isolates from 1997-1999, also in Papua New Guinea, showed increased genetic divergence in $S$. Typhi with PFGE, but only a restricted range of PFGE types were found in seven patients with severe or fatal disease [37]. Furthermore, recent studies have shown an association of the ciprofloxacin intermediate phenotype and the IncH1 MDR plasmid with H58 haplotype [38-40]. We have found that this particular haplotype has undergone widespread emergence in the Mekong Delta of Vietnam in the last 10 years [41]. Whether this haplotype is associated with more severe disease requires further investigation.

Our investigation has limitations that need to be considered. Firstly, we only studied hospital admitted cases 
Table 3 Clinical and haematological characteristics of 90 severe and 491 non-severe typhoid fever patients

\begin{tabular}{|c|c|c|c|c|c|}
\hline Characteristic & Severe or fatal $n=90$ & Non-severe $n=491$ & OR & $95 \% \mathrm{Cl}$ & $\mathrm{p}$ value \\
\hline \multicolumn{6}{|l|}{ Signs \& symptoms } \\
\hline Abdominal pain & $45(50.0)$ & $133(27.1)$ & 2.69 & $1.70-4.26$ & $<0.001$ \\
\hline Constipation & $29(32.2)$ & $105(21.4)$ & 1.75 & $1.07-2.86$ & 0.025 \\
\hline Diarrhoea & $62(68.9)$ & $259(52.7)$ & 1.98 & $1.23-3.21$ & 0.005 \\
\hline Vomiting & $30(33.3)$ & $86(17.5)$ & 2.36 & $1.43-3.87$ & 0.001 \\
\hline Cough & $21(23.3)$ & $110(22.4)$ & 1.05 & $0.62-1.80$ & 0.846 \\
\hline Headache & $42(46.7)$ & $178(36.3)$ & 1.54 & $0.98-2.42$ & 0.061 \\
\hline Temperature $>40^{\circ} \mathrm{C}$ & $50(58.1)$ & $268(56.5)$ & 1.07 & $0.67-1.70$ & 0.783 \\
\hline Systolic blood pressure $<90 \mathrm{mmHg}$ & $9(10.0)$ & $16(3.3)$ & 3.30 & $1.41-7.72$ & 0.004 \\
\hline Hepatomegaly & $62(68.9)$ & $241(49.1)$ & 2.30 & $1.42-3.71$ & 0.001 \\
\hline Splenomegaly & $19(21.1)$ & $82(16.7)$ & 1.34 & $0.76-2.33$ & 0.310 \\
\hline Rash & $5(5.6)$ & $10(2.0)$ & 2.83 & $0.94-8.48$ & 0.053 \\
\hline \multicolumn{6}{|l|}{ Haematology } \\
\hline Haematocrit $<30 \%{ }^{1}$ & $23(26.7)$ & 49 (11.3) & 2.85 & $1.63-5.01$ & $<0.001$ \\
\hline White cell count $<4 \times 10^{9} / L^{2}$ & $10(11.1)$ & $30(6.1)$ & 1.92 & $0.90-4.07$ & 0.086 \\
\hline White cell count $>15 \times 10^{9} / \mathrm{L}^{2}$ & $5(5.6)$ & $6(1.2)$ & 4.75 & $1.42-15.90$ & 0.006 \\
\hline Platelet count $<100 \times 10^{9} \mathrm{~L}^{3}$ & $7(9.9)$ & $20(5.8)$ & 1.77 & $0.72-4.35$ & 0.211 \\
\hline $\mathrm{SGOT}>200 \mathrm{IU} / \mathrm{L}^{4}$ & $33(63.5)$ & $30(17.9)$ & 7.99 & $4.01-15.91$ & $<0.001$ \\
\hline $\mathrm{SGPT}>200 \mathrm{IU} / \mathrm{L}^{4}$ & $28(53.8)$ & $16(9.5)$ & 11.08 & $5.24-23.47$ & $<0.001$ \\
\hline
\end{tabular}

${ }^{1} \mathrm{n}=518$.

${ }^{2} \mathrm{n}=580$.

${ }^{3} n=414$.

${ }^{4} n=220$.

and our data are, therefore, biased by factors that determine hospital admission such as pre-hospital treatment and access to healthcare. The lack of reliable data concerning pre-hospital antimicrobial therapy is a further drawback. The data are recorded from a period more than ten years ago and, therefore, may not represent the contemporary situation in Vietnam or in other parts of Asia. However, we selected this period as it covered a period of changing antimicrobial susceptibility patterns and strains. In many locations, which are currently endemic for typhoid, antimicrobial resistant strains now dominate the local epidemiology, making it difficult to determine any potential link between resistance and disease severity [41].

\section{Conclusion}

In this large dataset on clinical typhoid and disease severity we found an independent association between infections with strains with intermediate susceptibility to ciprofloxacin and severe typhoid fever. This may reflect the widespread use of fluoroquinolones, particularly ciprofloxacin and ofloxacin, in this area during this period

Table 4 Factors associated with severe or fatal typhoid fever

\begin{tabular}{|c|c|c|c|c|c|c|c|c|}
\hline Covariate & Severe or fatal $n=90$ & Non severe $n=491$ & OR & $95 \% \mathrm{Cl}$ & $\mathrm{p}$ value & AOR & $95 \% \mathrm{Cl}$ & $\mathrm{p}$ value \\
\hline Age (years) ${ }^{1}$ & $14(10-23)$ & $12(7-21)$ & 1.01 & $0.99-1.03$ & 0.243 & 1.02 & $0.99-1.04$ & 0.122 \\
\hline Male & $54(60.6)$ & $242(49.3)$ & 1.54 & $0.98-2.44$ & 0.062 & 1.61 & $1.00-2.57$ & 0.048 \\
\hline Days ill prior to admission ${ }^{1}$ & $10(7-14)$ & $8(6-10)$ & 1.03 & 0.99-1.07 & 0.081 & 1.04 & $.99-1.08$ & 0.065 \\
\hline Fully susceptible organism & $9(10.0)$ & $66(13.4)$ & 0.72 & $0.34-1.49$ & 0.371 & $\mathrm{NI}$ & & \\
\hline MDR & $78(86.7)$ & $391(79.6)$ & 1.66 & $0.87-3.17$ & 0.123 & 1.41 & $0.72-2.75$ & 0.316 \\
\hline Intermediate ciprofloxacin resistance & $45(50.0)$ & $170(34.6)$ & 1.89 & $1.20-2.97$ & 0.005 & 1.90 & 1.18-3.07 & 0.009 \\
\hline \multicolumn{9}{|l|}{ Site } \\
\hline Ho Chi Minh City & $52 / 350(14.9)$ & $298 / 350(85.1)$ & 1.00 & - & - & 1.00 & - & - \\
\hline Dong Thap & $38 / 231(16.5)$ & $193 / 231(83.5)$ & 1.13 & $0.72-1.78$ & 0.603 & 1.19 & $0.72-1.98$ & 0.501 \\
\hline
\end{tabular}

${ }^{1}$ Median (IQR).

AOR: adjusted odds ratio; NI: Not included. 
that are not fully effective against these infections. Whether additional host and bacterial factors are implicated in severe disease requires further investigation. Ciprofloxacin and ofloxacin should be used with caution in patients infected with $S$. Typhi that have intermediate susceptibility to ciprofloxacin. Although the newer generation fluorquinolone gatifloxacin is effective for treating such infections it is now unavailable in many countries because of safety concerns. Other alternatives for treating infections with isolates that are MDR and have intermediate susceptibility to ciprofloxacin are extended spectrum cephalosporins and azithromycin [42].

\section{Competing interests}

The authors declare that they have no competing interests.

\section{Authors' contribution}

CMP, CT, JJF and SB designed the study. CMP, HV, NTC, LTP, VAH, TTH, JW participated in data collection. CMP and CT analysed the data and wrote the first draft. All authors revised the manuscript for important intellectual content and read and approved the final version.

\section{Acknowledgements}

We thank the Directors, clinical and laboratory staff of the Hospital for Tropical Diseases and Dong Thap Provincial Hospital for their support of this study and the patients for their agreement to participate.

\section{Financial disclosure}

This work was supported by The Wellcome Trust of Great Britain. Stephen Baker is supported by a Sir Henry Dale Fellowship from the Royal Society and the Wellcome Trust. The funders had no role in study design, data collection and analysis, decision to publish, or preparation of the manuscript.

\section{Author details}

${ }^{1}$ Wellcome Trust Major Overseas Programme, Oxford University Clinical Research Unit, Hospital for Tropical Diseases, 764 Vo Van Kiet, District 5, Ho Chi Minh City, Vietnam. ${ }^{2}$ Department of Clinical Sciences, Liverpool School of Tropical Medicine, Pembroke Place, Liverpool, L3 5QA, UK. ${ }^{3}$ Nuffield Department of Clinical Medicine, Centre for Tropical Medicine, Churchill Hospital, Oxford, UK. ${ }^{4}$ Hospital for Tropical Diseases, 764 Vo Van Kiet, District 5, Ho Chi Minh City, Vietnam. ${ }^{5}$ Dong Thap Provincial Hospital, Cao Lanh, Dong Thap Province, Vietnam. ${ }^{6}$ Department of Medical Microbiology, University of East Anglia, Norwich, UK. ${ }^{7}$ London School of Hygiene and Tropical Medicine, Keppel Street, WC1E 7HT, London, UK.

Received: 7 October 2013 Accepted: 30 January 2014 Published: 10 February 2014

\section{References}

1. Buckle GC, Fischer Walker CL, Black RE: Typhoid fever and paratyphoid fever: Systematic review to estimate global morbidity and mortality for 2010. J Global Health 2012, 2:010401.

2. Ochiai RL, Acosta CJ, Danovaro-Holliday MC, Baiqing D, Bhattacharya SK, Actinic MD, Bhutta ZA, Cahn DG, Ali M, Shin S, Wain J, Page AL, Albert MJ, Farrar J, Abu-Elated R, Pang T, Galindo CM, von Seidlein L, Clemens JD: DOMI study typhoid group. A study of typhoid fever in five Asian countries: disease burden and implications for control. Bull WHO 2008, 86:260-268.

3. Parry CM, Hien TT, Dougan G, White NJ, Farrar JJ: Typhoid fever. New Engl J Med 2002, 347:1770-1782.

4. Butler T, Knight J, Nath SK, Speelman P, Roy SK, Azad MAK: Typhoid fever complicated by intestinal perforation: a persisting fatal disease requiring surgical management. Rev Infect Dis 1985, 7:244-256.

5. Van den Bergh ETAM, Gasem MH, Keuter M, Dolmans MV: Outcome in three groups of patients with typhoid fever in Indonesia between 1948 and 1990. Trop Med Int Health 1999, 4:211-215.

6. Bhutta ZA: Impact of age and drug resistance on mortality in typhoid fever. Arch Dis Child 1996, 75:214-217.
7. Butler T, Islam A, Kabir I, Jones PK: Patterns of morbidity and mortality in typhoid fever dependent on age and gender: review of 552 hospitalised patients with diarrhoea. Rev Infect Dis 1991, 13:85-90.

8. Chau TT, Campbell Jl, Galindo CM, Hoang NVM, Diep TS, Nga TT, Vinh Chau NV, Tuan PQ, Page AL, Ochiai L, Schultsz C, Wain J, Bhutta ZA, Parry CM, Bhattacharya SK, Dutta S, Agtini M, Dong B, Honghui Y, Anh DD, Canh DG, Naheed A, Albert MJ, Phetsouvanh R, Newton PN, Basnyat B, Arjyal A, La TTP, Rang NN, Phuong LT, Bay PVB, von Seidlein L, Dougan G, Clemens JD, Vinh H, Hien TT, Chinh NT, Acosta CJ, Farrar J, Dolecek C: Antimicrobial drug resistance of Salmonella enteric serovar Typhi in Asia and molecular mechanism of reduced susceptibility to the fluoroquinolones. Antimicrob Agents Chemother 2007, 51:4315-4323.

9. Lynch MF, Blanton EM, Bulens S, Polyak C, Vojdani J, Stevenson J, Medalla F, Barzilay E, Joyce K, Barrett T, Mintz ED: Typhoid fever in the United States, 1999-2006. JAMA 2009, 302:859-865.

10. Crump JA, Kretsinger K, Gay K, Hoekstra RM, Vugia DJ, Hurd S, Segler SD, Megginson M, Luedeman LJ, Shiferaw B, Hanna SS, Joyce KW, Mintz ED, Angulo FJ: Emerging Infection Program FoodNet, NARMS Working Group: Clinical response and outcome of infection with Salmonella enterica serotype Typhi with decreased susceptibility to fluoroquinolones: a United States FoodNet multicentre retrospective cohort study. Antimicrob Agents Chemother 2008, 52:1278-1284.

11. Parry CM, Vinh H, Chinh NT, Wain J, Campbell Jl, Hien TT, Farrar JJ, Baker S: The influence of reduced susceptibility to fluoroquinolones in Salmonella enterica serovar Typhi on the clinical response to ofloxacin therapy. PLoS Negl Trop Dis 2011, 5:e1163.

12. Stuart BM, Pullen RL: Typhoid. Clinical analysis of three hundred and sixty cases. Arch Intern Med 1946, 78:629-661.

13. Scragg J, Rubidge C, Wallace HL: Typhoid fever in African and Indian children in Durban. Arch Dis Child 1969, 44:18-28.

14. Duggan MB, Beyer L: Enteric fever in young Yoruba children. Arch Dis Child 1975, 1975(50):67-71.

15. Khan M, Coovadia YM, Connolly C, Sturm AW: Influence of sex on clinical features laboratory findings and complications of typhoid fever. Am J Trop Med Hyg 1999, 61:41-46.

16. Walia M, Gaind R, Mehta R, Paul P, Aggarwal P, Kalaivani M: Current perspectives of enteric fever: a hospital based study from India. Ann Trop Paed 2005, 25:161-174.

17. Wain J, Diep TS, Ho VA, Walsh AM, Hoa NTT, Parry CM, White NJ: Quantitation of bacteria in blood of typhoid fever patients and relationship between counts and clinical features, transmissibility and antimicrobial resistance. J Clin Microbiol 1998, 36:1683-1687.

18. Hoa NTT, Diep TS, Wain J, Parry CM, Hien TT, Smith MD, Walsh AL, White NJ: Community acquired septicaemia in southern Vietnam: the importance of multidrug resistant Salmonella typhi. Trans Roy Soc Trop Med Hyg 1998, 92:503-508.

19. Smith MD, Duong NM, Hoa NTT, Wain J, Ha HD, Diep TS, Day NPJ, Hien TT, White NJ: Comparison of ofloxacin and ceftriaxone for short-course treatment of enteric fever. Antimicrob Agents Chemother 1994, 38:1716-1720.

20. Vinh H, Wain J, Hanh VTN, Nga CN, Chinh MT, Bethell D, Hoa NTT, Diep TS, Dung NM, White NJ: Two or three days of ofloxacin treatment for uncomplicated multidrug-resistant typhoid fever in children. Antimicrob Agents Chemother 1996, 40:958-961.

21. Chinh NT, Solomon T, Thong MX, Ly LT, Hoa NTT, Wain J, Diep TS, Smith MD, Day NPJ, Phi LT, Parry CM, White NJ: Short courses of ofloxacin for the treatment of enteric fever. Trans R Soc Trop Med Hyg 1997, 91:347-349.

22. Chinh NT, Parry CM, Ly NT, Ha HD, Thong MX, Diep TS, Wain J, White NJ, Farrar JJ: A randomised controlled comparison of azithromycin and ofloxacin for treatment of multidrug-resistant or nalidixic acid resistant enteric fever. Antimicrob Agents Chemother 2000, 44:1855-1859.

23. Wain J, Bay PVB, Vinh H, Duong NM, Diep TS, Walsh AL, Parry CM, Hasserjian RP Ho VA, Hien TT, Farrar J, White NJ, Day NPJ: Quantitation of bacteria in bone marrow from patients with typhoid fever: relationship between counts and clinical features. J Clin Microbiol 2001, 39:1571-1576.

24. Vinh H, Parry CM, Hanh VTN, Chinh MT, House D, Tham CT, Thao NTT, Diep TS, Wain J, Day NPJ, White NJ, Farrar JJ: Double blind comparison of ibuprofen and paracetamol for adjunctive treatment of uncomplicated typhoid fever. Pediatr Infect Dis J 2004, 23:226-230.

25. Chanh NQ, Everest P, Khoa TT, House D, Murch S, Parry CM, Connerton P, Bay PV, Diep TS, Mastroeni P, White NJ, Hien TT, Ho VA, Dougan G, Farrar JJ, 
Wain J: A clinical, microbiological, and pathological study of intestinal perforation associated with typhoid fever. Clin Infect Dis 2004, 39:61-67.

26. Vinh H, Duong NM, Phuong LT, Truong NT, Bay PVB, Wain J, Diep TS, Ho VA, White NJ, Day NPJ, Parry CM: Comparative trial of short course ofloxacin for uncomplicated typhoid fever in Vietnamese children. Ann Trop Paed 2005, 25:17-22.

27. Parry CM, Ho VA, Phuong LT, Bay PVB, Lanh MN, Tung LT, Tham NTH, Wain J, Hien TT, Farrar JJ: Randomised controlled comparison of ofloxacin, azithromycin and an ofloxacin-azithromycin combination for treatment of multidrug-resistant and nalidixic acid resistant typhoid fever. Antimicrob Agents Chemother 2007, 51:819-825.

28. Clinical and Laboratory Standards Institute: Performance Standards for Antimicrobial Susceptibility Testing: 23rd Informational Supplement. CLSI document M100-S23: 33(1), Clinical and Laboratory Standards Institute. PA: Wayne; 2013.

29. Ferreccio C, Levine MM, Manterola A, Rodriguez G, Rivara I, Prenzel I, Black RE, Mancuso T, Bulas D: Benign bacteraemia caused by Salmonella typhi and paratyphi in children younger than 2 years. J Pediatr 1984 104:899-901.

30. Topley JM: Mild typhoid fever in children. Arch Dis Child 1986, 61:164-167.

31. Mahle WT, Levine MM: Salmonella typhi infection in children younger than five years of age. Pediatr Infect Dis J 1993, 12:627-631.

32. Kasper MR, Sokhal B, Blair PJ, Wierzba TF, Putnam SD: Emergence of multidrug- resistant Salmonella enterica serovar Typhi with reduced susceptibility to fluoroquinolones in Cambodia. Diag Micro Infect Dis 2010, 66:207-209.

33. Hoffman SL, Punjabi NH, Kumala S, Moechtar A, Pulungsih SP, Rivai RL, Rockhill RC, Woodward TE, Loedin AA: Reduction of mortality in chloramphenicol-treated severe typhoid fever by high dose dexamethasone. N Engl J Med 1984, 310:82-88.

34. Rogerson SJ, Spooner VJ, Smith TA, Richens J: Hydrocortisone in chloramphenicol treated severe typhoid fever in Papua New Guinea. Trans R Soc Trop Med Hyg 1991, 85:113-116.

35. Punjabi NH, Hoffman SL, Edman DC, Sukri N, Laughlin LW, Pulungsih SP, Rivai AR, Sutoto Moechtar A, Woodward TE: Treatment of severe typhoid fever in children with high dose dexamethasone. Ped Infect Dis J 1988, 7:598-600.

36. Thong KL, Passey M, Clegg A, Combs BG, Yassin RM, Pang T: Molecular analysis of isolates of Salmonella typhi obtained from patients with fatal and non-fatal typhoid fever. J Clin Microbiol 1996, 34:1029-1033.

37. Thong KL, Goh YL, Yasin RM, Lau MG, Passey M, Winston G, Yoannes M, Pang T, Reeder JC: Increasing genetic diversity of Salmonella enterica serovar Typhi isolates from Papua New Guinea over the period from 1992 to 1999. J Clin Microbiol 2002, 40:4156-4160.

38. Phan MD, Kidgell C, Nair S, Holt KE, Turner AK, et al: Variation in Salmonella enterica serovar Typhi IncH1 plasmids during the global spread of resistant typhoid fever. Antimicrob Agents Chemother 2009, 53:716-727.

39. Holt KE, Phan MD, Baker S, Duy PT, Nga TVT, Hinds J, Putcher P, Cooke FJ, Thomson NR, Titball R, Bhutta ZA, Hasan R, Dougan G, Wain J: Emergence of a globally dominant IncHI1 plasmid type associated with multiple drug resistant typhoid. PLoS Negl Trop Dis 2011, 5:e1245.

40. Romagnac P, Weill FX, Dolecek C, Baker S, Brisse S, Chinh NT, Le TAH, Acosta CJ, Farrar J, Dougan G, Achtman M: Evolutionary history of Salmonella Typhi. Science 2006, 314:1301-1304.

41. Holt KE, Dolecek C, Chau TT, Duy PT, La TTP, Hoang NVM, Nga NVT, Campbell Jl, Manh BH, Vinh Chau NV, Hien T, Farrar J, Dougan G, Baker S: Temporal fluctuation of multidrug resistant Salmonella Typhi haplotypes in the Mekong River Delta region of Vietnam. PLoS Neglect Trop Dis 2011, 5:e929.

42. Butler $\mathrm{T}$ : Treatment of typhoid fever in the $21^{\text {st }}$ Century: promises and shortcomings. Clin Microbiol and Infect 2011, 17:959-963.

doi:10.1186/1471-2334-14-73

Cite this article as: Parry et al:: Risk factors for the development of severe typhoid fever in Vietnam. BMC Infectious Diseases 2014 14:73.

\section{Submit your next manuscript to BioMed Central and take full advantage of:}

- Convenient online submission

- Thorough peer review

- No space constraints or color figure charges

- Immediate publication on acceptance

- Inclusion in PubMed, CAS, Scopus and Google Scholar

- Research which is freely available for redistribution 